\title{
The influence of employee engagement on labour productivity in an automotive assembly organisation in South Africa
}

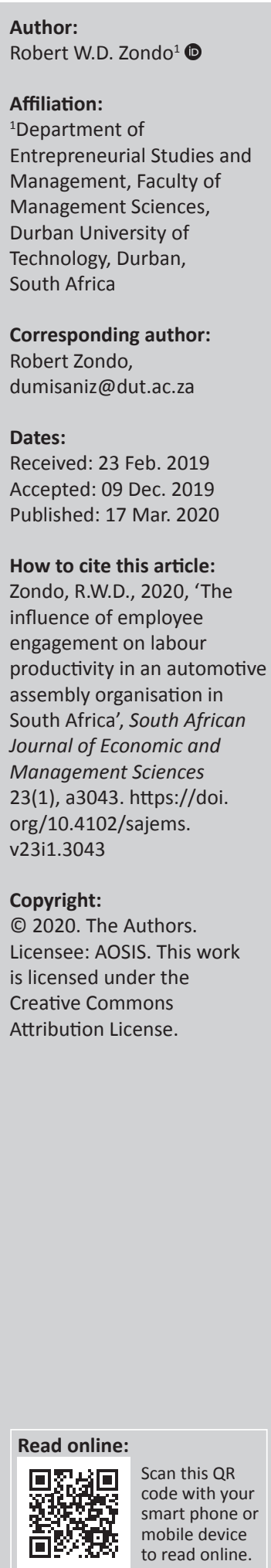

Background: Productivity of the South African work force remains an issue of central concern for business. It plays an important role in the life of every person and the performance of every business. Creating a working environment that encourages worker participation is one way to create the kind of workplace that attracts motivated work teams for productivity improvement. This sentiment underpins the concept of employee engagement. Employee engagement is the level of commitment and involvement an employee has towards their organisation and its values.

Aim: This study examines the influence of employee engagement on labour productivity improvement in the automotive assembly organisations in South Africa.

Settings: The study objectives were achieved by examining the production and related experiences of an automotive assembly organisation that has adopted an employee engagement strategy for labour productivity improvement. The company operates in the eThekwini District Municipality in KwaZulu-Natal. It assessed if employee engagement is responsible for company's labour productivity.

Method: The investigation was achieved by collecting quarterly data on absenteeism, employee participation in quality circles and labour productivity before and after the implementation of the strategy.

Results: Employee engagement does not have the ability to improve labour productivity in an automotive assembly organisation in South Africa. However, absenteeism rate has an influence on labour productivity resulting from the implementation of employee engagement.

Conclusion: South African organisations should revise their performance management systems and develop employee engagement strategies that help achieve new business goals. Consequently, this study uncovers the strengths and weaknesses of employee engagement for labour productivity improvement in South Africa.

Keywords: Absenteeism; Automotive assembly organisation; Employee engagement; Labour productivity; South Africa.

\section{Introduction}

South Africa's decline in labour productivity in the manufacturing sector is a cause for concern. Organisations are faced with the challenge of promoting innovative productivity improvement among employees (Zondo 2018). Hence, labour productivity plays a crucial role in the organisations' competitiveness. It represents the total volume of output (measured in terms of gross domestic product) produced per unit of labour (measured in terms of the number of employed persons) during a given time reference period (Parry \& Lacey 2000).

Its indicator allows the users to assess gross domestic product to labour input levels and growth rates over time, thus providing general information about the efficiency and quality of human capital in the production process for a given economic and social context, including other complementary inputs and innovations used in production. Thus, for an organisation to evolve, people working within it have to be involved in processes that improve the organisations' productivity (Zondo 2018). The people involving initiative form the basis for the philosophy of employee engagement.

Employee engagement is a psychological and physical demonstration of how the employee understands their role in the organisation, and the commitment of stewardship that manifests in high productivity levels of their work (Geldenhuys, Laba \& Venter 2014). This includes employees 
that promote their organisations and feel a sense of belonging and loyalty, and concerns with productivity as their roles (Guest 2014). Despite the acknowledgement of its importance in business, low levels of employee engagement are reported globally. Twenty-six per cent of employees are reported to be disengaged (Ariani 2013). Bersin (2015) lists the elements that relate to employee disengagement. These include the lack of meaningful work, a less inclusive workplace and the disregard for opportunities for growth. Hoxsey (2010) indicates that absenteeism can be an indicator of lack of employee engagement at work. If an organisation is subject to high levels of unplanned and unauthorised absence, it is essential to identify the root causes using an anonymous employee engagement survey.

In the United States (US), only 32\% of employees are actively engaged (Ariani 2013). Research estimates that a $21 \%$ increase in organisational profitability could result from the improvement in employee engagement levels in organisations. It is estimated that the effect of the disengaged employees costs US $\$ 11$ billion per annum. In South Africa, the Gallup 2016 survey indicates that 9\% of the South African workforce is actively engaged (Engagement 2017). On the other hand, it showed that $45 \%$ of the South African workforce was actively disengaged. It reported that less than $20 \%$ of the South African workforce's well-being is supported and their career development encouraged. Leadership and communication showed major shortfalls resulting in low engagement levels. In addition, Engagement (2017) indicates that the majority of the South African workforce believe that they neither have the autonomy nor opportunity to contribute on issues that affect their work. Out of the South Africans surveyed, 20\% felt no connection to their work.

Kahn (1990) describes employee engagement as the employment and expression of a person's preferred self in task behaviour. Employee engagement has emerged in business as one of the key factors that organisations ought to prioritise in order to remain competitive. Geldenhuys et al. (2014) showed a positive relationship between psychological meaningfulness and work engagement and that meaningful work plays a significant role in employee engagement and sustaining employee commitment as well as productivity. Gems (2015) states that work meaningfulness contributes to the core of the organisation. Similarly, Bakker, Demerouti and Sanz-Vergel (2014) investigated the role of psychological conditions in employee engagement using a cross-sectional design. Their results showed the significant role played by psychological meaningfulness in employee engagement. According to Gems (2015), during the process of engagement, employees become self-motivated and are driven and energised to perform to the organisation's expectations. Thus, Chaudhuri (1986) indicates that quality circles have been the popular employee engagement technique among organisations pursuing excellence. Hence, motivation and related techniques tend to be the constructs and predictors of employee engagement and organisational outcomes. Other studies by Ghadi, Fernando and Caputi (2013), Anitha (2014), Guest (2014), and Kaliannan and Adjovu (2014) examined the relationships between variables like transformational leadership, compensation, training and development, workplace well-being, teams and co-workers, as well as work environment with employee engagement. It established that these factors determine the extent to which employees are engaged. They are the case predictors of employee engagement. Guest (2014) adds that productivity improvement is sustainable when everyone in the organisation, from top management to workers on the shop floor, is engaged. Participatory mechanisms through engagement philosophy come in various forms, from simple suggestion schemes to interlocking problem-solving groups at all levels in the hierarchy. These participatory productivity improvement schemes are more effective when problem-solving activities are coordinated with and linked to the overall company productivity improvement priorities and strategies.

\section{Problem statement: Low labour productivity level in South Africa}

There is a lack of participation in productivity initiatives at shop floor level in South Africa and companies are faced with competitive challenges of promoting innovativeness relating to productivity improvement among employees (Zondo 2018). Its labour productivity, in the manufacturing sector, is low when compared to Korea, the United States of America (USA), Taiwan, Japan, France and the United Kingdom(UK) (Klein 2012). TheSouth African manufacturing industry achieved only $36 \%$ of the USA labour productivity level in 2014 (The Conference Board 2015). Hence, this study investigates whether employee engagement strategy has the ability to improve labour productivity in the selected automotive assembly organisation in South Africa. Studies that show a link between employee engagement and labour productivity are lacking. Previous studies (Ahmed \& Dajani 2015; Farouk 2014; Jose \& Mampilly 2012) have not shown the effectiveness of employee engagement as an intervening variable for labour productivity in the automotive manufacturing industry in South Africa. Hence, this study evaluates its influence on labour productivity in an automotive assembly organisation in South Africa.

\section{Literature review}

This section presents the overview of employee engagement, the empirical evidence of employee engagement, as well as employee engagement and company productivity.

\section{Overview of employee engagement}

Employee engagement is defined as a positive attitude held by the employee towards the organisation and its value (AbuKhalifer \& Som 2013). An engaged employee is aware of business context and works with colleagues to improve performance within the job for the benefit of the organisation. It is the harnessing of organisational members to their work roles. During employee engagement, people employ and express themselves physically, cognitively and emotionally during role performance (Gems 2015). Engagement (2017) defined employee engagement as a positive, fulfilling, 
work-related state of mind that is characterised by vigour, dedication, and absorption. Hence, Cherry (2016) defined it as the level of commitment and the involvement an employee has towards their organisation and its values. Hoxsey (2010) studied the relationship between employee engagement, organisational commitment and absenteeism. He indicates that, by looking at employees' absenteeism records, an organisation could pinpoint which employees may not be engaged in their current job. When a member of staff is unexpectedly absent from work, it raises an immediate cause for concern with regard to the likelihood of missing deadlines, disruption to the quality and continuity of service delivery, loss of productivity and efficiency, as well as a drop in motivation and employee engagement. Thus, Jose and Mampilly (2012) described employee engagement as the degree to which individuals are attentive and absorbed in the performance of their roles. Consequently, this study assesses the influence of employee engagement on labour productivity in an automotive assembly organisation in South Africa.

\section{Empirical evidence of employee engagement}

A number of studies were conducted aimed at establishing the value of employee engagement in companies.

A study by Jose and Mampilly (2012) indicates that an organisation's overall employee engagement level is directly influenced by employee satisfaction, commitment, loyalty and performance. In illustrating the benefits of measuring employee engagement and working strategies to improve employee engagement, Jose and Mampilly revealed that companies with higher levels of employee engagement have higher levels of profits that are derived from productivity. Berdarka and Pandita (2014) presented the key drivers of employee engagement. These include communication, worklife balance and leadership. Organisations and employees are both dependent on each other to fulfil their goals and objectives. Hence, employee engagement should not be a one-time exercise but should be integrated in the organisational culture. Bhuvanaiah and Raya (2014) discuss a positive behaviour that is associated with an engaged workforce. Employee engagement must be managed. This results from employee differences in personality, interest and abilities (Gems 2015).

Kaliannan and Adjovu (2014) refer to engaged employees as satisfied and committed, who immerse themselves in the successful attainment of organisational goals and are the force behind organisational success.

Engagement (2017) identified employee engagement drivers as perceived support, job characteristics, value congruence and internal communication. On measuring the benefits of employee engagement, Jose and Mampilly (2012) composed a scorecard to measure engagement levels. Their organisational scorecards are founded on the basic theory that the overall organisation's employee engagement level is directly influenced by the component of engagement that includes employee satisfaction, loyalty and performance.
Jose and Mampilly refer to employee engagement as a primary source of competitive advantage. This can be understood as a measure of organisational productivity. Gandy et al. (2014) assess employee engagement as a key to organisations realising their competitive advantage, while Gems (2015) discussed a connection between employee engagement and organisational outcomes. They explain that when the work environment is conducive to employees focusing their attention on their work and being motivated to do their best, productivity levels experienced by the organisations are high.

\section{Employee engagement and company productivity}

A meta-analytical study conducted by Harter et al. (2013) examined the relationship between employee engagement and performance. It revealed that employee engagement has a significant impact on employee performance, which is a predictor of productivity. Thus, labour productivity becomes an important indicator that is closely linked to economic growth, competitiveness and living standards within the economy (Parry \& Lacey 2000). It is a key measure of human and economic performance. If an organisation has employees whose engagement levels are above average, it is twice as likely to be successful (Farouk 2014). Hence, employee engagement does influence organisational productivity. Gems (2015) indicates that engaged employees are more productive than disengaged. Consequently, low levels of employee engagement are detrimental to performance. Farouk (2014) explains that engaged employees exercise an element of care in what they do as well as in their efforts to contribute to the success of the organisation. They will have a greater sense of ownership and accountability. Employees will become less absent from work and more willing to take on more responsibility and initiatives. The study on 100 best places to work, as conducted by Anitha (2014), reveals that employees who have established an engaged relationship with management had a low turnover rate of $13 \%$. They are more committed, loyal to their organisation and less inclined to leave their organisation as they feel a sense of belonging. Jose and Mampilly (2012) state that good communication is necessary to keep employees engaged with the organisation's priorities.

Consequently, the absence of good communication leads to poor engagement and low productivity.

Communication methods such as one-on-one build engagement with employees (Ahmed \& Dajani 2015).

In an effort to facilitate good communication, Engagement (2017) encourages organisations to nurture communication by listening to employees' concerns, thus encouraging employees to participate in workplace discussions. This results in productivity improvement. Hence, Anitha (2014) indicates that employee engagement is a lever gearing the organisations towards success through productivity. It is an investment that can elicit good returns. Farouk (2014) identified strategies that can be used to boost employee engagement as employee 
training and development, as well as improved leadership and work design. In addition, Kaliannan and Adjovu (2014) presented numerous drivers of employee engagement. These include two-way communication, as well as training and development.

\section{Two-way communication}

Leadership, communication and a work-life balance were determined by Ahmed and Dajani (2015) as drivers of employee engagement. Similarly, Cherry (2016) deduced that a culture of respect, constant feedback from management, counselling and mentoring are drivers of employee engagement. Dulagil (2012) explains that if there is to be any level of engagement, there needs to be clear communication of the core values and beliefs of employees. Transparency about the goals and objectives of the organisation should be evident. Supervisors and managers should demonstrate care about the health and well-being of the employees (Dulagil 2012).

There should also be person-job fit alignment so that people are placed in their areas of capabilities. Farouk (2014) explored the attitude of employees on productivity. If employees are included in the decision-making process on matters concerning their work, there will be positive benefits for both the employees and the organisation. If organisations endeavour to improve the process of informing employees about changes in relation to their work environment, employees would be more likely to suggest improvements, which in turn increase productivity.

\section{Training and development}

Leadership, compensation, training and development, as well as workplace well-being are the drivers of employee engagement (Anitha 2014). However, training and development are recognised by Cherry (2016) as the important determinants of engagement levels for employees. The determinants increase the ability of employees to perform better, thereby contributing to productivity improvement. As a result, this study investigates whether employee engagement has the ability to improve labour productivity in the automotive sector. It explores the suitability of employee engagement as an appropriate tool for labour productivity improvement.

\section{Employee engagement through quality circles}

While Chaudhuri (1986) defined quality circle as a small group of people doing similar work who meet voluntarily on a regular basis, usually under the leadership of their supervisor, to discuss their work problems, it has evolved into a structured system to harness a collective wisdom on employee engagement in an organisation. It enhances participation and employee engagement in work-related decisions. A study of a quality circle of weekly meetings of supervisors and employees in a unionised foundry to discuss means of improving productivity showed that higher levels of employee engagement were related to increases in a productivity index incorporating such variables as scrap rate and production output (Marks et al. 1986). Hence, quality circles lead to high internal work motivation, high quality work performance and satisfaction with work, as well as low absenteeism.

\section{Hypothesis}

The study is based on the following assumption:

H1: The implementation of employee engagement leads to labour productivity improvement in the automotive assembly organisation.

$\mathrm{H}_{0}$ : The implementation of employee engagement does not lead to labour productivity improvement in the automotive assembly organisation.

The following are sub-hypotheses:

H2: An increase in the absenteeism rate increases labour productivity in the automotive assembly organisation.

H2: An increase in the absenteeism rate decreases labour productivity in the automotive assembly organisation.

H3: An increase in the rate of employee participation in quality circles increases labour productivity in the automotive assembly organisation.

$\mathrm{H}_{0}$ : An increase in the rate of employee participation in quality circles decreases labour productivity in the automotive assembly organisation

\section{Methodology}

The method for this research will be discussed under the following headings research design and approach, company that participated in the study, data collection, as well as the measurement and data analysis.

\section{Research design and approach}

This study was quantitative in nature. It examines the relationship of labour productivity as a dependent variable with absenteeism rate and employee participation in quality circles, as well as post-employee engagement dummy. Bryman and Bell (2007) explain that the quantitative approach involves the use of statistical procedures to analyse the data collected. Consequently, after the measurements of the relevant variables, the scores were transformed using statistical methods. The study was also conclusive in design. Conclusive studies are meant to provide information that is useful in decision-making (Yin 2008).

\section{Company that participated in the study}

A convenience sample from one large automotive assembly organisation situated within the eThekwini District Municipality in the province of KwaZulu-Natal in South Africa was used. The company had adopted an employee engagement strategy and agreed to participate in the study. It implemented an employee engagement strategy in order to give employees the platform to raise issues and concerns they come across (on a daily basis) in their workplaces. The strategy also aimed at improving employee skills so that they could produce products that satisfy the customers. Consequently, employee engagement was employed on the company's blue-collar employees whose jobs require manual 
TABLE 1: Percentage breakdown of employees in terms of their level of activities.

\begin{tabular}{lc}
\hline Level of activity & $\mathbf{\%}$ \\
\hline Plant management & 4.7 \\
Support administration staff & 9.2 \\
Team leaders & 7.1 \\
Line functional employees & 79.0 \\
\hline
\end{tabular}

labour. The company had 1403 employees. It operates a three-shift system. Table 1 presents a percentage breakdown of employees in terms of their level of activities.

\section{Data collection}

The collection of data from the company that participated in the study was carried out in two phases. This involved the collection of results pre- and post-employee engagement from company records for absenteeism, the rate of employee participation in quality circles, and labour productivity. The pre-employee engagement results were quarterly data reflecting the company's performance over the three-year period prior to employee engagement implementation. This includes data from the first quarter of 2014 to the final quarter of 2016. The post-employee engagement data reflect the company's performance for two years after employee engagement was implemented. This includes data from the first quarter of 2017 to the final quarter of 2018 .

\section{Measurement and data analysis}

The company's quarterly time-series data on absenteeism, labour productivity, and the rate of employee participation in quality circles were used. The measurements were based on a total of 60 observations. A dummy variable which assumed a value of 0 and 1 to represent pre- and post-employee engagement was introduced into the ordinary least squares (OLS) model. The aim was to isolate the pre- and post-labour productivity effects. Consequently, if employee engagement proved to be a useful strategy in raising labour productivity levels, this would result in a statistically significant coefficient on the dummy variable.

The OLS model, analysed using the Statistical Package for Social Sciences (SPSS) version 23.0, was as follows: Labour Productivity $=\mathrm{B}_{0}+\mathrm{B}_{1}$ Rate of Employee Participation in Quality Circles $+\mathrm{B}_{2}$ Absenteeism Rate $+\mathrm{B}_{3}$ Pre/Post Dummy.

The above model identifies labour productivity as a function of rate of employee participation in quality circles, the absenteeism rate and the employee engagement strategy.

In addition, the normality test was conducted using Kolmogorov-Smirnov and Shapiro-Wilk for the overall score of the constructs. Table 2 presents results for normality tests for labour productivity rate, the rate of employee participation in quality circles as well as the absenteeism rate.

Statistical tests in Table 2 showed that the data were not normally distributed $(p>0.05)$. Hence, the study was analysed using parametric tests, that is, the t-tests.
TABLE 2: Normality tests for labour productivity rate, the rate of employee participation in quality circles as well as the absenteeism rate.

\begin{tabular}{lcccc}
\hline Variable & Group & Statistic & $d f$ & Significance \\
\hline Kolmogorov-Smirnov $\dagger$ & & & & \\
Labour productivity rate & 0 & 0.143 & 12 & $0.200^{*}$ \\
Rate of employee participation in & 0 & 0.210 & 12 & $0.200^{*}$ \\
quality circles & 1 & 0.188 & 8 & $0.200^{*}$ \\
Absenteeism rate & 0 & 0.217 & 12 & $0.200^{*}$ \\
& 1 & 0.201 & 8 & $0.200^{*}$ \\
Shapiro-Wilk & & & & \\
- & - & 0.930 & 12 & 0.514 \\
- & - & 0.927 & 8 & 0.574 \\
- & - & 0.843 & 12 & 0.082 \\
- & - & 0.961 & 8 & 0.814 \\
- & - & 0.880 & 12 & 0.189 \\
- & - & 0.966 & 8 & 0.847 \\
\hline
\end{tabular}

*, This is a lower bound of the true significance.

$\dagger$, Lilliefors significance correction.

\section{Study results}

This section analyses the results for pre- and post-employee engagement means comparison, as well as labour productivity.

\section{Pre- and post-employee engagement means comparison}

Table 3 compares the means (in percentages) for employee participation in quality circles, absenteeism and labour productivity.

Results in Table 3 indicate that the percentage mean data for pre-employee engagement on employee participation in quality circle, absenteeism and labour productivity are $31.25 \%, 21.75 \%$ and $42.63 \%$. In addition, the percentage mean data for post-employee engagement on employee participation in quality circle, absenteeism and labour productivity are $43.0 \%, 31.20 \%$ and $71.80 \%$. The results show an increase in mean values on all three variables (that is, the employee participation in quality circles, absenteeism, as well as labour productivity) from the pre-employee engagement to post-employee engagement periods.

\section{Labour productivity results}

Table 4 presents the results for labour productivity as a dependent variable to the rate of employee participation in quality circles, absenteeism, as well as post-employee engagement dummy.

\section{Labour productivity as a dependent variable to employee participation rate in quality circles}

The results show that the employee participation rate in quality circles has no relationship with labour productivity. This is determined by its $t$-value of 1.723 . The value is below the critical $t$-value of 1.960 at the $5 \%$ level of significance (Curwin \& Slater 2002), thus accepting the null hypothesis of a relationship between labour productivity and employee participation rate in quality circles. This indicates that the employee participation rate in quality circles is independent of labour productivity. 
TABLE 3: Pre- and post-employee engagement percentage means comparison.

\begin{tabular}{lccc}
\hline Variable & $\begin{array}{c}\text { Pre-employee } \\
\text { engagement } \\
\text { period (\%) }\end{array}$ & $\begin{array}{c}\text { Post-employee } \\
\text { engagement } \\
\text { period (\%) }\end{array}$ & $\begin{array}{c}\% \text { mean } \\
\text { difference } \\
\text { (pre- post) }\end{array}$ \\
\hline $\begin{array}{l}\text { Employee participation } \\
\text { in quality circle }\end{array}$ & 31.25 & 43.00 & -11.75 \\
Absenteeism & 21.75 & 31.20 & -9.45 \\
Labour productivity & 42.63 & 71.80 & -29.17 \\
\hline
\end{tabular}

TABLE 4: Labour productivity results on the rate of employee participation in quality circles, absenteeism rate, as well as post-employee engagement dummy.

\begin{tabular}{|c|c|c|c|}
\hline Regression & Coefficient & $t$-statistic & Probability \\
\hline Constant $\left(\mathrm{B}_{0}\right)$ & -3.912 & -3.912 & 0.004 \\
\hline $\begin{array}{l}\text { Rate of employees' } \\
\text { participation in } \\
\text { quality circles }\end{array}$ & 9.347 & 1.723 & 0.119 \\
\hline Absenteeism rate & 0.457 & 1.980 & 0.079 \\
\hline $\begin{array}{l}\text { Employee engagement } \\
\text { dummy }\end{array}$ & 0.216 & 0.945 & 0.369 \\
\hline$R$-squared & 0.761 & F-statistics & 9.529 \\
\hline Adjusted $R^{2}$ & 0.681 & Sum of squares & 2.340 \\
\hline $\begin{array}{l}\text { Standard error of } \\
\text { regression }\end{array}$ & 0.286 & $\begin{array}{l}\text { Durbin-Watson } \\
\text { statistic }\end{array}$ & 1.416 \\
\hline
\end{tabular}

Note: Regression data: 2014-2018 for 60 observations. The following OLS estimation is based on the equation: Labour Productivity $=B_{0}+B_{1}$ Rate of Employee Participation in Quality Circles $+B_{2}$ Absenteeism Rate $+B_{3}$ Pre/Post Dummy.

\section{Labour productivity as a dependent variable to absenteeism rate}

Results as illustrated in Table 4 show that absenteeism rate has a relationship with labour productivity. This is determined by its $t$-value of 1.980 . The value is above the critical $t$-value of 1.960 at the $5 \%$ level of significance, thus accepting the assumption of a significant relationship between labour productivity and the absenteeism rate. This indicates that the absenteeism rate is dependent on labour productivity.

\section{Labour productivity as a dependent variable to an employee engagement dummy variable}

Results show that employee engagement has no relationship with labour productivity. This is determined by its $t$-value of 0.945 which is below the critical $t$-value of 1.960 at the $5 \%$ level of significance, thus accepting the null hypothesis of a relationship between labour productivity and employee engagement. This indicates that the employee engagement is independent of labour productivity. It has an adjusted $R^{2}$ of 0.681 . Furthermore, the serial correlation is also low at 1.416 when compared to the standard value of 1.72 at the $5 \%$ level of significance (Curwin \& Slater 2002).

\section{Summary of results: Statistical tests and box plots for determining whether the normality and homogeneity of variances have been met}

This section analyses data using factorial designs. It incorporates box plots to determine whether the factorial analysis of variance assumptions of normality and homogeneity of variance have been met. Porkess (2005) explains that the populations represented should be normally distributed (that is, the normality), making the mean an

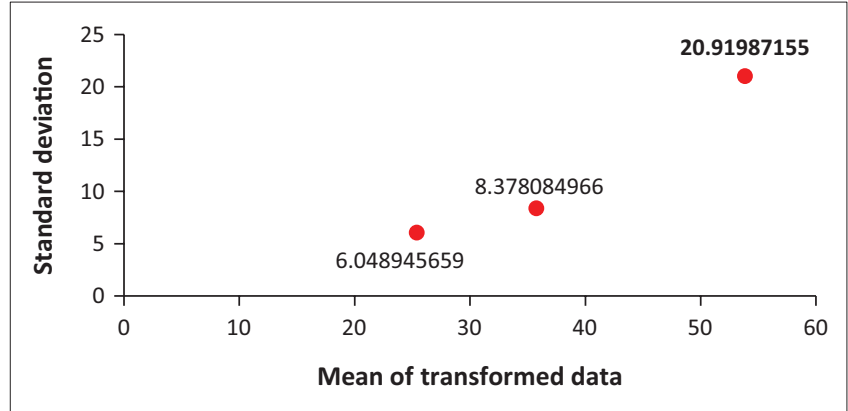

FIGURE 1: Bartlett's test for homogeneity of variances.

TABLE 5: Bartlett's test for homogeneity of variances $(p=0.001)$.

\begin{tabular}{lcc}
\hline Variable & $\begin{array}{c}\text { Means of transformed } \\
\text { data }\end{array}$ & $\begin{array}{c}\text { Standard deviations of } \\
\text { transformed data }\end{array}$ \\
\hline Labour productivity & 53.846 & 20.920 \\
$\begin{array}{l}\text { Employee participation } \\
\text { in quality circles }\end{array}$ & 35.769 & 8.378 \\
Absenteeism & 25.385 & 6.049 \\
\hline
\end{tabular}

TABLE 6: Levene's test of equality.

\begin{tabular}{lcc}
\hline Fisher-Snedecor & $t$-statistic & Significance \\
\hline 5.502 & -3.308 & 0.007 \\
\hline
\end{tabular}

appropriate measure of central tendency. However, the homogeneity of variance indicates that the population from which the data are sampled should have the same variance.

The Bartlett's test was used to verify whether the variances were equal for all the samples (Curwin \& Slater 2002). Figure 1 presents a summary of the results from the Bartlett's test for homogeneity of variances.

In addition, Table 5 presents detailed results of the Bartlett's test for homogeneity of variances for labour productivity, employee participation in quality circles as well as absenteeism.

The $p$-value in the Bartlett's test (at $p<0.05$ ) shows that the homogeneity of variances has occurred, thus rejecting the null hypothesis. The $p$-value at 0.001 is low as compared with the significance level of 0.05 . We can conclude that there are distribution changes between the two parts of time-series. This is confirmed by Levene's test of equality shown in Table 6 .

Porkess (2005) defines Levene's test of equality as an inferential statistic used to assess the equality of variance on different samples. In Levene's test of equality, the statistical procedure assumes that variances of the populations from which different samples are drawn are equal. As a result, the findings in Table 6 show that the obtained similarities between the variances in the samples for pre- and post-data at $p$-value 0.007 have occurred. They are below the statistical significant level of 0.05. Box plots in Figure 2 confirm the results.

Figure 2 shows that the mode of change from pre-to post-employee engagement period is homogeneous. Box plots indicate a similar spread of employee engagement results. Statistical tests suggest that the conditions for 


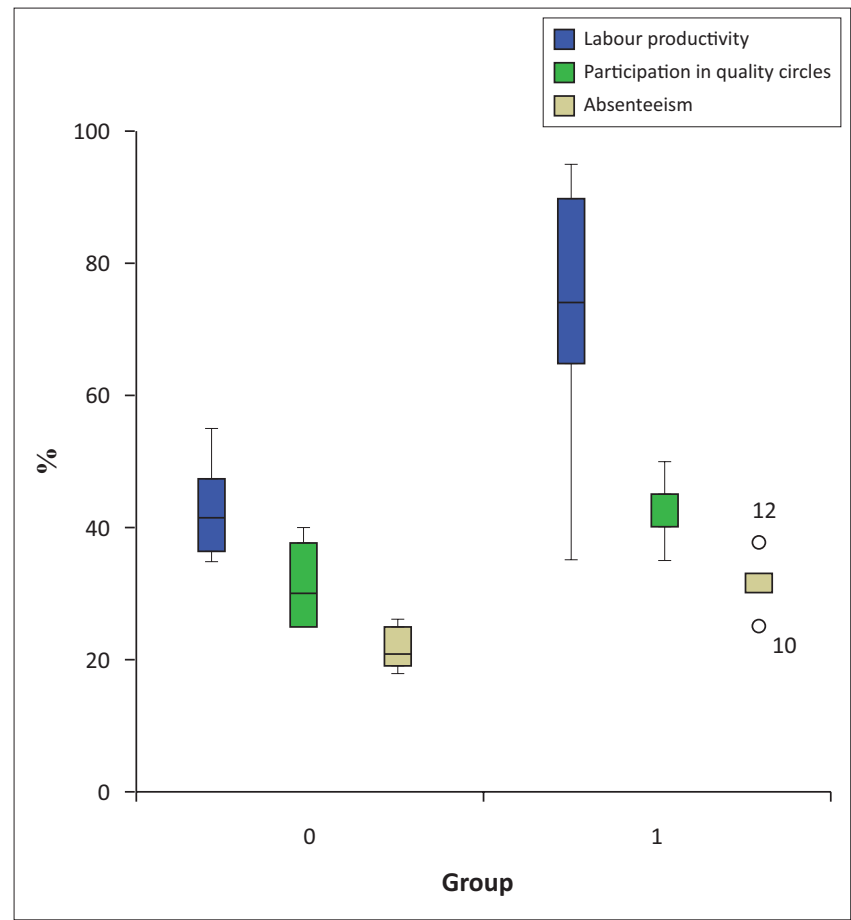

FIGURE 2: Box plots determining the normality and homogeneity of variance.

homogeneity of variances between pre- and post-employee engagement have been met.

\section{Discussion}

This study investigates the influence of employee engagement on the improvement of labour productivity in an automotive assembly organisation in South Africa. It examined the production and related experience of the automotive assembly organisation that has adopted an engagement strategy among its employees.

Quarterly time-series data on absenteeism, labour productivity and employee participation in quality circles were used to analyse data. The results indicate that absenteeism rate has a relationship with labour productivity.

However, employee participation in quality circles and employee engagement have no relationship with labour productivity in the automotive assembly organisation in South Africa. Geldenhuys et al. (2014) presented the number of conditions that lead to the success of employee engagement. There should be a positive relationship between psychological meaningfulness of work and employee engagement. An absence of meaningful work contributes to employee engagement failures, resulting in low labour productivity.

\section{Implications of results for policy and practice}

Organisations in South Africa should revise their performance management systems and develop employee engagement strategies, policies and practices that help to achieve new business goals and support organisational and cultural change (Smith 2007). This must be based on an understanding of the economic factors affecting employee engagement and motivation, as well as the significance of the psychological meaningfulness of work that influences employee engagement for labour productivity improvement. Besides the achievement of study objectives, the following conclusions can be made on the employee engagement philosophy:

- It is a lever gearing the organisations towards success through labour productivity.

- It can negatively be affected by the lack of meaningful work, a less inclusive workplace and the disregard for opportunities for growth.

- In order to maximise performance, a comprehensive performance policy must be developed, which aligns employee engagement to labour productivity (Farouk 2014).

\section{Study limitations}

The study was limited to an automotive assembly organisation within the eThekwini District Municipality.

The investigation was conducted in a single company that has adopted an employee engagement strategy.

As there are eight registered assembly companies in South Africa (SAinfo 2008), the results cannot be extrapolated to other companies within the sector. Secondly, it did not examine the process followed during employee engagement, including (among others) the individuals that participated in the implementation process. It used only quarterly time-series data to determine the pre-and post-labour productivity effects resulting from the employee engagement strategy. Lastly, the econometrics model used was of the OLS variety, solely due to data constraints. Future studies ought to use the more advanced Johansen value at risk methodology or panel data analysis, both of which rely on large data sets.

\section{Conclusion}

An employee engagement process creates a working environment that encourages worker participation and commitment. Properly implemented and managed, the system results in improved employee performance.

Psychological meaningfulness and motivation play a role in employee engagement. Hence, the relationship between absenteeism rate and labour productivity exists after the employee engagement is implemented. However, there was no direct relationship between employee engagement and labour productivity in the selected automotive assembly organisation. The system is not a solution to inherent labour productivity problems. It is an approach that takes advantage of a focused organisational strategy to combine employee communication, decision-making and participation. The system can be used for developing employee capability in the organisations. Thus, the employees will have the capabilities to solve organisational problems (Brewster et al. 2003). 


\section{Future research required}

During the course of this study, issues relating to the long-term survival of an employee engagement strategy after implementation were not covered. This includes the applicability of employee engagement to a wider sector of the economic activity, including the public sector. The nature of this research did not allow these areas to be covered in depth. It is recommended that future research should examine the following issues in greater depth:

- When to use and when not to use an employee engagement system.

- The applicability of an employee engagement approach to other industrial sectors.

- The process followed during the implementation of an employee engagement system.

- A more comprehensive investigation should be carried out using a randomised sample of the registered automotive manufacturers that use an employee engagement strategy to see if the results can be generalised.

\section{Acknowledgements Competing interests}

The author declares that he has no financial or personal relationships that may have inappropriately influenced him in writing this article.

\section{Author's contributions}

I declare that I am the sole author of this research article.

\section{Funding information}

The article was paid for by the Durban University of Technology (DUT) researcher fund.

\section{Ethical considerations}

The researcher complied to the following: the process for the collection of data did not involve access to confidential personal data; the research fulfils the criteria for informed consent; respondents were not asked to perform any acts or make statements that might be expected to cause discomfort; the researcher did not expect to obtain any direct or indirect financial or other benefits from conducting the research.

\section{Data availability statement}

Data sharing is not applicable to this article as no new data were created or analysed in this study.

\section{Disclaimer}

The views and opinions expressed in this article are those of the authors and do not necessarily reflect the official policy or position of any affiliated agency of the authors.

\section{References}

AbuKhalifer, A.N. \& Som, A.P.M., 2013, 'The antecedents affecting employee engagement and organizational performance', Asian Social Science 9(7), 112-121. https://doi.org/10.5539/ass.v9n7p41

Adair, C., MacPherson, D. \& Oehler, K., 2017, 2017 trends in global employee engagement, Aon Hewitt, Deerfield, IL.

Ahmed, M. \& Dajani, Z., 2015, 'The impact of employee engagement on job performance and organizational commitment in the Egyptian banking sector', Journal of Business and Management Studies 3(5), 445-451.

Anitha, J., 2014, 'Determinates of employee engagement and their impact on employee performance', International Journal of Productivity and Performance Management 63(3), 308-323. https://doi.org/10.1108/IJPPM-01-2013-0008

Ariani, D.W., 2013, 'The relationship between employee engagement, organizational citizenship behaviour, and counter-productive work behaviour', International Journal of Business Administration 4(2), 46-56. https://doi.org/10.5430/ijba. v4n2p46

Bakker, A.B., Demerouti, E. \& Sanz-Vergel, A.I., 2014, 'Burnout and work engagement: The JD-R approach', The Annual Review of Organizational Psychology and Organizational Behaviour 1, 389-411. https://doi.org/10.1146/annurev-orgpsych031413-091235

Berdarkar, M. \& Pandita, D., 2014, 'A study on the drivers of employee engagement impacting employee performance', Procedia - Social and Behavioural Sciences 1(33), 106-115. https://doi.org/10.1016/j.sbspro.2014.04.174

Bersin, J., 2015, Becoming irresistible: A new model for employee engagement, viewed19 September 2017, from, www.dupree.deloitte.com

Bhuvanaiah, T. \& Raya, R.P., 2014, 'Employee engagement: Key to organizational success', Journal of Indian Management 11(4), 61-71.

Brewster, C., Carey, L., Dowling, P., Globler, P. \& Wärnich, S., 2003, Contemporary issues in human resource management: Gaining a competitive advantage, Oxford University Press, Cape Town.

Bryman, A. \& Bell, E., 2007, Business research methods, Oxford University Press, Oxford, NY.

Cherry, K., 2016, What is self-determination theory?, viewed 06 April 2017, from www. verywell.com.

Chaudhuri, K.K., 1986, 'Quality circles - A way of enhancing employee participation', Indian Journal of Industrial Relations 21(3), 356-368.

Conference Board, 2015, Productivity brief 2015: Global productivity stuck in the slow lane with no signs of recovery in sight, Conference Board, New York.

Curwin, J. \& Slater, R., 2002, Quantitative methods for business decisions, British Library Cataloguing Data, London.

Dulagil, A., 2012, 'The relationship of employee engagement and wellbeing to organizational and student outcomes', SBS HDR Student Conference, Wollongong, Australia, August 06, 2012, n.p.

Engagement, 2017, Kelly rapid talent development, viewed 11 June 2017, from www. kelly.co.za.

Farouk, I., 2014, 'Exploring employee attitude and productivity at electrical company of Ghana', MBA Thesis, Ashanti-East.

Gallup, 2016, Gallup, viewed 11 June 2017, from www.q12.gallup.com.

Gandy, W.M., Coberly, C., Pope, J.E. \& Wells, A., 2014, 'Comparing the contributions of well-being and disease status to employee productivity', Journal of Occupational and Environmental Medicine 56(3), 252-257. https://doi.org/10.1097/JOM. 0000000000000109

Geldenhuys, M., Laba, K. \& Venter, C.M., 2014, 'Meaningful work, work engagement and organisational commitment', Journal of Industrial Psychology 40(1), Art, \#1098, 10 pages. https://doi.org/10.4102/sajip.v40i1.1098

Gems, E., 2015, New perspectives in employee engagement in human resources, Emerald Group Publishing Limited, Bingley, UK.

Ghadi, M.Y., Fernando, M. \& Caputi, P., 2013, 'Transformational leadership and work engagement: The mediating effect of meaning in work', Leadership and Organizational Development Journal 34(6), 532-550. https://doi.org/10.1108/ LODJ-10-2011-0110

Guest, D., 2014, 'Employee engagement: A sceptical analysis', Journal of Organisationa Effectiveness: People and Performance 1(2), 141-156. https://doi.org/10.1108/ JOEPP-04-2014-0017

Harter, J.K., Schidt, F.L., Agrawal, S. \& Plowman, S.K., 2013, 'The relationship between engagement at work and organizational outcomes', Gallup 1(3), 1-29.

Hoxsey, D., 2010, 'Are happy employees healthy employees? Researching the effects of employee engagement on absenteeism', Canadian Public Administration 53(1), 551-571. https://doi.org/10.1111/j.1754-7121.2010.00148.x

Jose, G. \& Mampilly, S.R., 2012, 'Satisfaction with HR practices and Employee Engagement: A social exchange perspective', Journal of Economics and Behavioural Studies 4(7), 423-430.

Kahn, W.A., 1990, 'Psychological conditions of personal engagement and disengagement at work', Academy of Management Journal 33(4), 692-734. https://doi.org/10.5465/256287

Kaliannan, M. \& Adjovu, S.N., 2014, 'Winning the talent war via effective employee engagement: A case study', Journal of Business and Financial Affairs 3, 132. https://doi.org/10.4172/2167-0234.1000132 
Klein, N., 2012, Real wage, labour productivity, and employment trends in South Africa: A closer look, IMF WP/12/92, International Monetary Fund, Washington, DC.

Marks, M.L., Hackett, E.J., Mirvis, P.H. \& Grady, J.F., 1986, 'Employee participation in a quality circle program: Impact on quality of work life, productivity, and absenteeism', Journal of Applied Psychology 71(1), 61-69. https://doi.org/ 10.1037/0021-9010.71.1.61

Parry, T. \& Lacey, P., 2000, 'Promoting productivity and workforce effectiveness', Financial Executive 16(6), 51-53.

Porkess, R., 2005, Collins internet-linked dictionary of statistics, HarperCollins, Glasgow.
SAinfo, 2008, South Africa's automotive industry, viewed 14 October 2017, from http://www.southafrica.info/doing_business/economy/key_sectors/motorin dustryboost.html

Smith, I., 2007, 'Reward management and HRM', in P. Blyton \& E. Turnbull (eds.) Re-assessing human resource management, pp. 16-32, Sage, London.

Yin, R.K., 2008, Handbook of Applied Research: California, Sage, Thousand Oaks, CA.

Zondo, R.W.D., 2018, 'The impact of gainsharing in the automotive parts manufacturing industry of South Africa', South African Journal of Economic and Management Sciences 21(1), a1773. https://doi.org/10.4102/sajems.v21i1.1773 